\title{
New Method for the Assessment of Biological Effect by Surfactants Using Yeast DNA Microarray
}

\author{
Sakiko Kurita $^{1 *, 2}$, Sophon Sirisattha ${ }^{1}$, Emiko Kitagawa ${ }^{1}$, \\ Yuko Momose ${ }^{1}$, Kuniko AKAmA ${ }^{2}$, Yutaka Ishigami ${ }^{3}$ and Hitoshi IwAHASHI ${ }^{1}$ \\ ${ }^{1}$ National Institute of Advanced Industrial Science and Technology \\ (Central 6, 1-1-1, Higashi, Tsukuba, Ibaraki 305-8566, JAPAN) \\ ${ }^{2}$ Graduate School of Science and Technology, Chiba University \\ (1-33,Yayoi-cho, Inage-ku, Chiba-shi, Chiba 263-8522 JAPAN) \\ ${ }^{3}$ Tokyo Gakugei University \\ (Koganei, Tokyo 184-8501, JAPAN)
}

Edited by N. Yamamoto, Lion Corp., and accepted April 5, 2004 (received for review February 23, 2004)

\begin{abstract}
Spiculisporic acid (a biosurfactant produced by Penicillium spiculisporum) is used in the preparation of detergents, gelation agents, coloring agents for concrete, vesicle forming agents, etc. The effects of biosurfactant and synthetic surfactants (SDS and LAS) were assessed for the first time in this study at the genomic level by yeast DNA microarray bioassay. Hierarchical clustering showed spiculisporic acid to be close to LAS and SDS. The effects of spiculisporic acid on yeast cells would thus appear basically the same as those of LAS and SDS. Gene induction by spiculisporic acid was particularly remarkable in functional categories of "metabolism", while "cell rescue defense and virulence" and "energy" categories differed from those with SDS and LAS. Thus, spiculisporic acid and SDS might be metabolized via betaoxidation in two different organelles, mitocondria and peroxisome, respectively. This would explain the low oxidative stress with spiculisporic acid, versus the high oxidative stress with SDS.
\end{abstract}

Key words: surfactant, microarray, yeast, supiculisporic acid

\section{1 はじめに}

生物は種々の界面活性物質を合目的に自家生産し， 利用している。このような生物由来の界面活性物質は, 胆汁酸, ソープフィッシュのペプチドリピッド（動物 由来)，サポニン，ロジン (植物由来)，スピクリス ポール酸, ソホロリピッド, サーファクチン，イチュ リン（微生物由来）など多岐にわたる。スピクリス ポール酸（Fig. 1）（1）は糸状菌が産生する三塩基酸型 の長鎖脂肪酸であって, 多官能性のために様々の誘導 体がファインケミカルズとして利用でき，またそのア ルカリ塩は界面活性剤となる（2）。多岐にわたり利用
できることから環境に対する影響を調査し，これまで に安全性 (急性毒性, 魚毒性, 刺激性, 変異原性) - 生 分解性に優れることが示されているが，詳細な影響評 価は行われていない（3）。一方，合成界面活性剂は生 産量も多く, 陰イオン性界面活性剂では, 水道水水質 基準值 $0.2 \mathrm{ppm}$ が設定されており（4），影響評価に関 する研究も多い(5)。

最近になりDNA マイクロアレイ法が開発され，本研 究室では酵母の DNA マイクロアレイを化学物質の影響 評価を行う手法として用いている。酵母 DNA マイクロ アレイは，1枚のスライドガラス上に酵母の全遺伝子で ある約 6000 種のプローブが搭載されているもので，化

\footnotetext{
${ }^{*}$ Correspondence to: Sakiko KuRITA, National Institute of Advanced Industrial Science and Technology, Central 6, 1-1-1, Higashi, Tsukuba, Ibaraki 305-8566, JAPAN

E-mail: h06942@kasumi.nibh.jp
} 
学物質添加条件下で培養した酵母と, 化学物質非添加 条件下で培養した䤉母の cDNA を混合させて一枚のマ イクロアレイ上で結合させることにより，化学物質の 影響評価を遺伝子発現レべルで比較できるものである。 既にその有用性が，いくつかの化学物質について報告 されている。ドデシル硫酸ナトリウム（SDS）や直鎖 アルキルベンゼンスルホン酸ナトリウム (LAS) のよう な合成界面活性剤についてもその影響が DNA マイクロ アレイを用いて報告された（5）。これら合成界面活性 剂は, DNA マイクロアレイ解析により, 従来から報告 されていたように, 酵母細胞の膜構造に影響を与える ことや酸化ストレスを誘発している事を示す結果を再 確認すると共に, 解毒機構としては, 新たに, 能動的 排出系である PDR ネットワークが関与していることを 示す結果を得ている（5）。そこで今回は，これまでに あまり研究されていない生物由来界面活性剤のモデル としてスピクリスポール酸が酵母細胞に与える影響を 観察すると共に，比較対照として合成界面活性剂であ るSDS および LAS を用いて, 微生物の遺伝子発現レべ ルでの影響を解析し，DNA マイクロアレイ技術の有用 性を検証した。(http://kasumi.nibh.jp/ iwahashi/)

\section{2 実験方法}

\section{$2 \cdot 1$ 試料}

スピクリスポール酸は, 磐田化学工業(株) より恵与 されたもので, (4S, 5S)-4,5-dicarboxy-4-pentadecanolide の構造を持ち，エタノールー水系により精製して使用 した (6)。 $\mathrm{C}_{17} \mathrm{H}_{28} \mathrm{O}_{6}=328.54$ として, 元素分析の実測 值（計算値）は, C: $62.22 \%$ (62.17\%), H: 8.59 \% (8.59\%), O: $29.20 \%$ (29.23\%); mp. $146^{\circ} \mathrm{C} ;[\alpha]_{\mathrm{D}}{ }^{26}=-12.6(\mathrm{c}=$ $3.28 \mathrm{~g} / \mathrm{dl}$, ethanol)であった。化学構造式を Fig. 1 に示 した（1）。ドデシル硫酸ナトリウム（SDS）はSIGMA 製，直鎖アルキルベンゼンスルホン酸ナトリウム （LAS）は和光純薬工業(株) 製をそのまま用いた。その 他の薬品は市販試薬を用いた。

\section{$2 \cdot 2$ 培養条件}

本実験で使用した酵母は, Saccaromyese sereviciae $\mathrm{S} 288 \mathrm{C}$ 株 (suc2 mal gal2 CUP1)で, $25^{\circ} \mathrm{C}$ 条件下, YPD 液体培地で振とう培養を行った。スピクリスポール酸 処理をした酵母は, $\mathrm{A}_{660}=1.0$, すなわち対数増殖期に DMSO に溶解したスピクリスポール酸を添加し，2 時 間培養したものを使用した。また，スピクリスポール 酸処理をした酵母の比較対照となる酵母は, $\mathrm{A}_{660}=1.0$ の時にスピクリスポール酸の溶媒であるDMSO を同量 添加し， 2 時間培養したものを使用した。

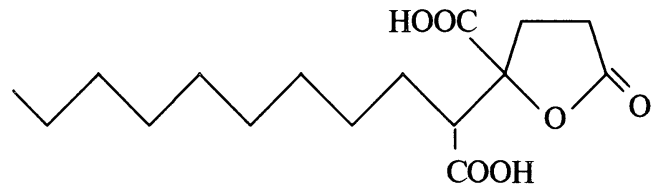

Fig. 1 Structural Diagram of Supiculisporic Acid. Chemical name of supiculisporic acid is (4S,5S)-4-5-dicarboxy-4pentadecanolide.

\section{$2 \cdot 3$ 酵母 DNA マイクロアレイ}

65 度のホットフェノール法により, スピクリスポー 儿酸添加条件下で培養した酵母打よび, 非添加条件下 で培養した酵母から Total RNA を抽出し, つづいて, Oligotex - dT30（TAKARA）を使って，mRNAの精製 を行った。次に，スピクリスポール酸添加条件下の mRNA 蛍光色素 Cy3，スピクリスポール酸非添加条 件の mRNA を蛍光色素 Cy5 でそれぞれラベルした標識 cDNAを合成し，これらを混合して一枚の DNA マイク ロアレイ(Ver.1.1:DNA チップ研究所)にハイブリダイ ゼーションを行った（7）。処理の終わったマイクロア レイはScan array4000 (GSI Lumonics)でイメージ画像 にし, GenePix (Axon Instruments, Inc. CA, USA)で定量 化を行った（7）。

\section{$2 \cdot 4$ マイクロアレイデータの数值化と定量法}

定量化したデータを Genespring (Silicon genetics)で 解析するために, Chip Cleanser（(独)産業技術総合研 究所 古賀氏作成）を使用して正規化を行った。Chip Cleanserでは，イメージ画像で得られたそれぞれのス ポットの蛍光強度からそれぞれのバックグラウンドを 差し引くことと, 167 個あるネガティブコントロールス ポットの蛍光強度の平均值に 2 倍の標準偏差を加えた 值より小さい蛍光強度のスポットを切り捨てることで, 正確性に欠けるスポットや, 非特異的にハイブリダイ ズしたスポットの排除を行った。それぞれのマイクロ アレイの実験を正規化するために, Cy5 の蛍光強度を $\mathrm{Cy} 3$ の蛍光強度で割った值の平均值を計算し, 全体の 平均值として用いた。この方法により正規化したデー タをGenespringで解析した。また信頼性を得るため に, 同条件で 3 回実験を行った。

\section{5 階層的クラスター解析}

階層的クラスター解析 (Fig. 2) には GeneSpring を 使用した（8）。それぞれの化学物質により誘導された 遺伝子の類似性は相関係数により求めた。分離率は 1.0 で, 最小距離は 0.001 とした。蛍光強度が低い遺伝子を 含めると, 不正確な結果になる可能性が高いことから, 
これまでに蓄積したマイクロアレイデータにおいて， 20 種類（Fig. 2）の化学物質による少なくとも 1 種以 上の化学物質で，蛍光強度が平均值以上で誘導してい た遺伝子 3874 種を選択し, 階層的クラスター解析の計 算に使用した。

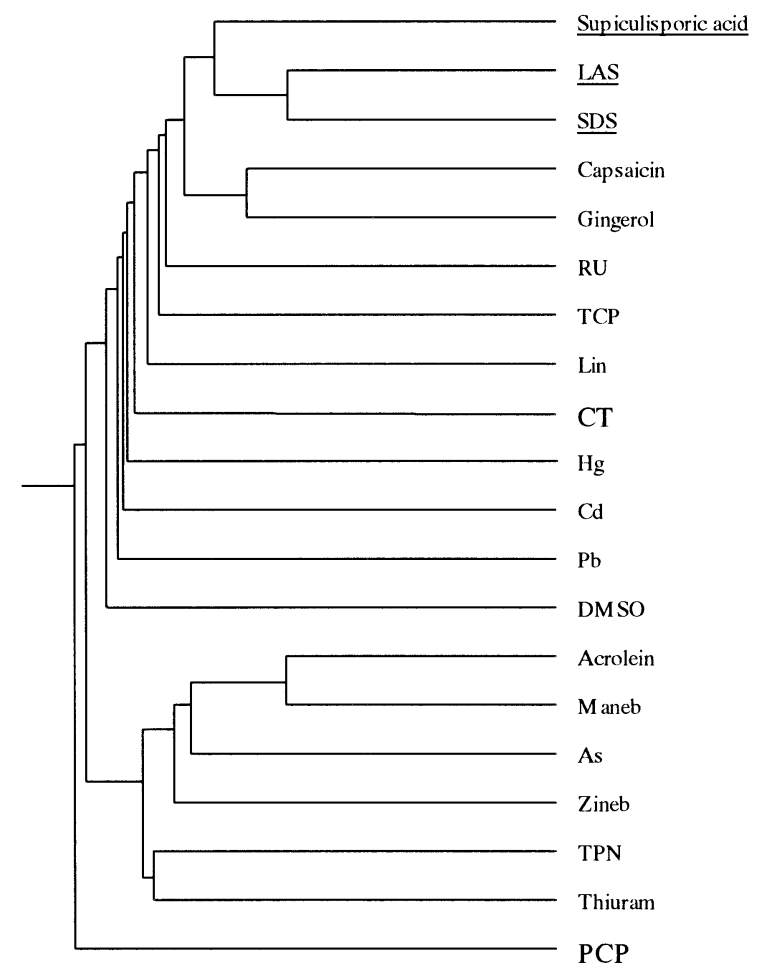

Fig. 2 Hierarchical Clustering of Genome-Wide Expression Profiles in Response to Supiculisporic Acid and Other Chemicals. Yeast cells were treated with different chemicals for two hours as follows: Supiculisporic acid $(0.16 \%)$, sodium n-dodecyl benzene sulfonate (LAS) $(0.02 \%)$, sodium dodecyl sulfate $(\operatorname{SDS})(0.01 \%)$, capsaicin $(0.82 \mathrm{mM})$, gingerol (1.36 mM), Roundup (Japan Monsanto Co. Ltd.)(RU) (1500 times dilution), 2,4,5trichlorophenol (TCP) $(16 \mu \mathrm{M})$, lindane (1.3 mM), $10 \mu \mathrm{M}$ Cadmium $+1.5 \mu \mathrm{M}$ Thiuram (CT), mercuric chloride $(\mathrm{Hg})$ (0.7 $\mathrm{mM})$, cadmium chloride $(\mathrm{Cd})(0.3 \mathrm{mM})$, lead chloride (PB) $(2 \mathrm{mM})$, dimethylsulfoxide(DMSO) $(10 \%, 1.41 \mathrm{M})$, acrolein (0.20 mM), maneb (2 ppm), sodium arsenite (As) (0.3 $\mathrm{mM})$, zineb (2ppm), TPN $(10 \mu \mathrm{M})$, thiuram $(75 \mu \mathrm{M})$, and PCP $(50 \mu \mathrm{M})$. (http://kasumi.nibh.jp/ iwahashi/)

\section{3 結果と考察}

\section{$3 \cdot 1$ スピクリスポール酸処理条件の検討}

実験に使用する濃度を決定する為に，スピクリス ポール酸の濃度を変えて, 酵母の生育に与える影響を 調べた結果を Table 1 に示す。これに基づき， $\mathrm{IC}_{50}$ に 相当する $0.16 \%$ 条件で培養した酵母を以下の DNA マ イクロアレイの実験に用いることにした。今回の実験 結果との比較対象である界面活性剂の SDS は $0.01 \%$, LAS は $0.02 \%$ 濃度で, これは $\mathrm{IC}_{50}$ に相当する条件で あることから (http://kasumi.nibh.jp/ iwahashi/), IC $_{50}$ で統一することにした。スピクリスポール酸の $\mathrm{IC}_{50}$ は SDS の 16 倍, LAS の 8 倍で酵母に対する毒性が低いこ とを確認した。

\section{$3 \cdot 2$ 階層的クラスター解析を用いた各化学物質処理 による遺伝子発現の比較}

mRNAの発現プロファイルを, 他の化学物質と比べ る為に階層的クラスター解析を行った（Fig. 2）（8）。 対照化学物質としては農薬, 重金属, 天然化合物, な どを利用した(http://kasumi.nibh.jp/ iwahashi/)。その 結果，3種類の界面活性剂は，比較的近い枝で結ばれて おり，発現プロファイルが似ていると判断されている。 なかでも，SDS と LAS は枝の距離が近いことから，遺 伝子の発現プロファイルがよく似ていると判断されて いる。また，ジンジャオールやカプサイシン（9）とも 近似しているのがわかる。以上の結果は，その化学構 造から推定できる生体に対する影響の類似性を示して おり, DNA マイクロアレイ法が, 界面活性剂等の化学 物質の影響評価に利用できる可能性を示している。さ らに，スピクリスポール酸による生体への影響を，ス ピクリスポール酸, SDS, LASによって誘導された遺 伝子を比較しながら解析することにした。

Table 1 The Effect of Supiculisporic Acid on the Growth of Yeast Cells.

\begin{tabular}{ccccc}
\hline$\%$ & 0 & 0.08 & 0.16 & 0.25 \\
\hline 0 hour & 1.0 & 1.0 & 1.0 & 1.0 \\
2 hours & 1.7 & 1.6 & 1.4 & 1.2 \\
\hline
\end{tabular}

A stock solution of supiculisporic acid (1M in DMSO) was added to the YPD medium before inoculation with the final concentrations of $0 \%, 0.08 \%, 0.16 \%, 0.25 \%$. Growth was monitored as the absorbance at $660 \mathrm{~nm}$. 
$3 \cdot 3$ スピクリスポール酸, SDS, LAS の処理によっ て高く発現した遺伝子とその共通性

今回解析したスピクリスポール酸, 既に報告されて いるSDS，LASでそれぞれ誘導，または抑制された遺 伝子の数をべンダイヤグラム（Fig. 3）で重ね合わせ た。スピクリスポール酸非添加条件下で培養した酵母 の mRNAに比べ，スピクリスポール酸添加条件下で培 養した䣲母の mRNA が，3 回の実験中 2 回以上の実験 で 2 倍以上発現していたものを誘導遺伝子, 同様に 0.5 倍以下のものを抑制遺伝子とした（8）。誘導された遺 伝子は約 6000 種中, 既報のように SDS では 333 種, LAS では 176 種，一方，スピクリスポール酸では 376 種であり，そのうち 3 種の界面活性剤で共通して誘導 された遺伝子は 20 種であった。SDS と LAS で共通し て誘導されている遺伝子は 117 種, SDS とスピクリス ポール酸では 50 種, LAS とスピクリスポール酸では 31 種であった。抑制された遺伝子はSDSで 131 種，LAS では 51 種，スピクリスポール酸で 355 種であり，3 種 で共通して抑制された遺伝子は 1 種であった。スピク リスポール酸はLAS と SDSに比べて, 共通する遺伝子 が半分以下であった。スピクリスポール酸と SDS，あ るいはスピクリスポール酸と LAS で共通して誘導され た遺伝子数は, SDS と LAS で共通して誘導された遺伝 子数と比べて少ないことから, バイオサーファクタン トであるスピクリスポール酸と陰イオン性界面活性剤 では，細胞に対する影響が異なることが考えられる。

3 種類の界面活性剤でそれぞれ強く誘導してされてい た，上位 20 種の遺伝子を Table 2 に示す。Table 2 中 に下線で示したものは上位 20 種の遺伝子中， 2 種類以 上の界面活性剤で共通して誘導された遺伝子である。 既報のようにSDS と LAS は, 上位 20 種の中だけでも 半数以上の遺伝子が共通して誘導されていたが，スピ
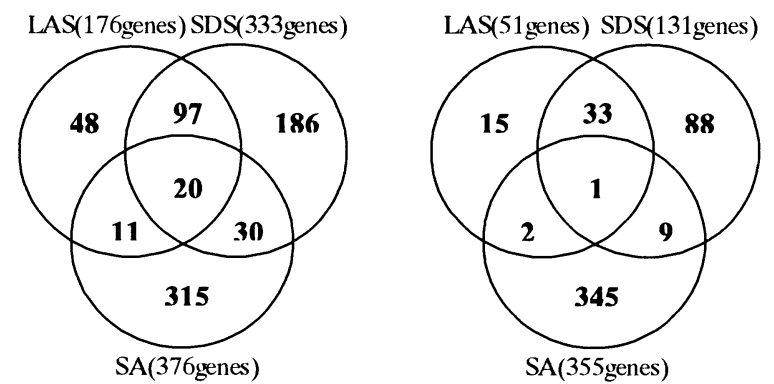

Fig. 3 Venn Diaglram of the Number of Overlapping and Non-Overlapping Induced and Reduced Gene. The left side of venn diaglam shows induced genes treated with surfactants. The right side of venn diaglam shows repressd genes treated with surfactants.SA, Supiculisporic acid.
クリスポール酸は，SDS，またはLASに共通した遺伝 子が上位 20 種中，2 種だけであった。Fig. 2 に示した クラスター解析では同じ枝に分類されているが, 細胞 に対する作用はスピクリスポール酸とSDS, LASでは 異なることが Table 2 からも示されており，DNA マイ クロアレイの有効性を示す結果でもある。

\section{$3 \cdot 4$ 誘導遺伝子および抑制遺伝子の機能的分類と遺 伝子産物の局在性}

遺伝子にはそれぞれ機能があり，誘導された遺伝子 の機能を解析することで化学物質の生体に対する影響 を評価することができる。タンパク質のデータベース である MIPS (http://www.mips.biochem.mpg.de/proj/ yeast/)では, 酵母の各遺伝子を「エネルギー」,「細胞 の救出」,「防御系」などの機能別に分類し, 19 のカテ ゴリーを作っている。それぞれのカテゴリーに属する サブカテゴリーまで併せると， 259 ものカテゴリーがあ り，機能別に遺伝子を分類するのに便利である。そこ で，3種の界面活性剤で誘導された遺伝子をMIPSのカ テゴリーに従って分類した結果を Fig. 4 に示した。ス ピクリスポール酸では「エネルギー」,「輸送促進」,

Table 2 The List of Significantly Induced Genes by the Treatment with Each Detergent.

\begin{tabular}{llllll}
\hline \multicolumn{1}{r}{ SA } & \multicolumn{3}{c}{ SDS } & \multicolumn{2}{c}{ LAS } \\
\hline TIR1 & 8.6 & HSP12 & 9.3 & $\underline{\text { RTA1 }}$ & 13.6 \\
YHM1 & 8.3 & $\underline{\text { POX1 }}$ & 9.2 & $\underline{\text { YLR346C }}$ & 12.3 \\
YNL194C & 7.2 & $\underline{\text { RTA1 }}$ & 8.8 & $\underline{\text { INO1 }}$ & 10.4 \\
PRM7 & 5.8 & $\underline{\text { YPL088W }}$ & 8.2 & $\underline{\text { YPL088W }}$ & 9.7 \\
HEM13 & 5.7 & $\underline{\text { ECI1 }}$ & 8.1 & $\underline{\text { MET30 }}$ & 7.5 \\
YDL037C & 5.5 & $\underline{\text { YMR107W }}$ & 8.0 & YLL056C & 6.9 \\
YOR049C & 5.5 & $\underline{\text { YLR346C }}$ & 7.6 & $\underline{\text { DIA1 }}$ & 6.9 \\
OPI3 & 5.0 & $\underline{\text { YHR138C }}$ & 7.1 & CMK2 & 5.5 \\
YOL162W & 4.9 & $\underline{\text { YNL211C }}$ & 6.9 & $\underline{\text { YHR138C }}$ & 5.0 \\
DAN1 & 4.7 & $\underline{\text { YOR385W }}$ & 6.3 & $\underline{\text { YLR046C }}$ & 5.0 \\
PDR15 & 4.7 & $\underline{\text { DIA1 }}$ & 6.2 & YGR212W & 5.0 \\
AGP1 & 4.7 & $\underline{\text { PDR15 }}$ & 5.9 & YOR152C & 4.9 \\
YGR131W & 4.6 & $\underline{\text { MET30 }}$ & 5.7 & $\underline{\text { PHO89 }}$ & 4.9 \\
YDL123W & 4.6 & $\underline{\text { YHR140W }}$ & 5.5 & $\underline{\text { YLR008C }}$ & 4.9 \\
YER188W & 4.5 & $\underline{\text { GRE2 }}$ & 5.4 & $\underline{\text { YHR054C }}$ & 4.6 \\
YER067W & 4.5 & $\underline{\text { YFL027C }}$ & 5.2 & $\underline{\text { GRE2 }}$ & 4.6 \\
BIO2 & 4.4 & $\underline{\text { YLR046C }}$ & 5.2 & $\underline{\text { YNL211C }}$ & 4.5 \\
YNL024C & 4.4 & $\underline{\text { MSC1 }}$ & 5.1 & $\underline{\text { YLR414C }}$ & 4.4 \\
$\underline{\text { INO1 }}$ & 4.3 & $\underline{\text { YLR327C }}$ & 5.1 & SMP1 & 4.4 \\
YIR035C & 4.3 & $\underline{\text { PB12 }}$ & 5.1 & $\underline{\text { YER130C }}$ & 4.2 \\
\hline
\end{tabular}

Gene name with line shows commonly induced genes. 
「代謝系」，一方，既報のようにSDSでは「エネルギー」， 「細胞の救出, 防御系」,「代謝系」, LAS では「細胞の 救出, 防御系」,「細胞環境に打ける相互関係の調節に 分類されている遺伝子」,「エネルギー」が高い割合で 誘導されている。スピクリスポール酸で「輸送促進系」 の遺伝子が多く誘導されていたのが特徴的であった。 また，抑制遺伝子をカテゴリーに従って分類したとこ ろ（Fig. 5)，スピクリスポール酸では「タンパク質合 成系」, 「細胞間の伝達や情報伝達の機構に関する遺伝 子」, 「未分類遺伝子」, SDS では「細胞組織の調節系」, 「転写系」,「タンパク質合成系」, LAS では「輸送促進」, 「細胞組織の調節系」,「タンパク質合成系」が高い割合 で抑制されていた。

界面活性剤は細胞膜に影響を与えることが広く知ら れていることから, スピクリスポール酸, SDS, LAS で誘導された遺伝子産物が細胞内オルガネラのどこに 局在しているかを, MIPSのデータベースを基に分類し た（Fig. 6)。スピクリスポール酸では，「ミクロソー ム」,「細胞壁」, SDSでは「ミクロソーム」,「ペルオキ シソーム」, LAS では「ペルオキシソーム」,「液胞」に 多く局在していることが分かった。さらに Table 3 に 細胞膜に局在する遺伝子産物を示した。細胞膜に関与 する遺伝子数は, 誘導遺伝子で 3 種類の界面活性剤と も同程度であった。しかし，既報のようにSDS と LAS
では同じ遺伝子が誘導されていたのに比べ，スピクリ スポール酸で誘導された遺伝子はそのほとんどが, 他 の 2 種類の界面活性剤と異なる遺伝子であった。SDS と LAS では「解毒系」に関与する遺伝子が誘導されて いたのに対して，スピクリスポール酸では「輸送系」 に関与する遺伝子の誘導がみられた。3 種類の界面活性 凨とも, 細胞膜に関係する遺伝子が誘導されていたが, 膜に対する影響は違うものと考える。これらの結果も， スピクリスポール酸と陰イオン性界面活性郕による生 体影響が異なることを示している。

スピクリスポール酸で特徴的であった，「輸送促進」 のカテゴリーの遺伝子をさらに細かく見るために，「輸 送促進」に属するサブカテゴリーで分類した結果を Fig. 7 に示す。スピクリスポール酸で高い割合で誘導 されているサブカテゴリーの上位 5 項目では, SDS, LAS による誘導がほとんど見られなかった。逆に， SDSによって高く誘導されているサブカテゴリーでは， スピクリスポール酸による誘導率は低かった。また， スピクリスポール酸は「輸送促進」のカテゴリーに関 する遺伝子が 35 種誘導されていたのに詨し, SDSでは 16 種, LASでは 10 種と少なかった。

\section{$3 \cdot 5$ エネルギーに関する誘導遺伝子}

3 種の界面活性剂で共通して高い割合で誘導されてい

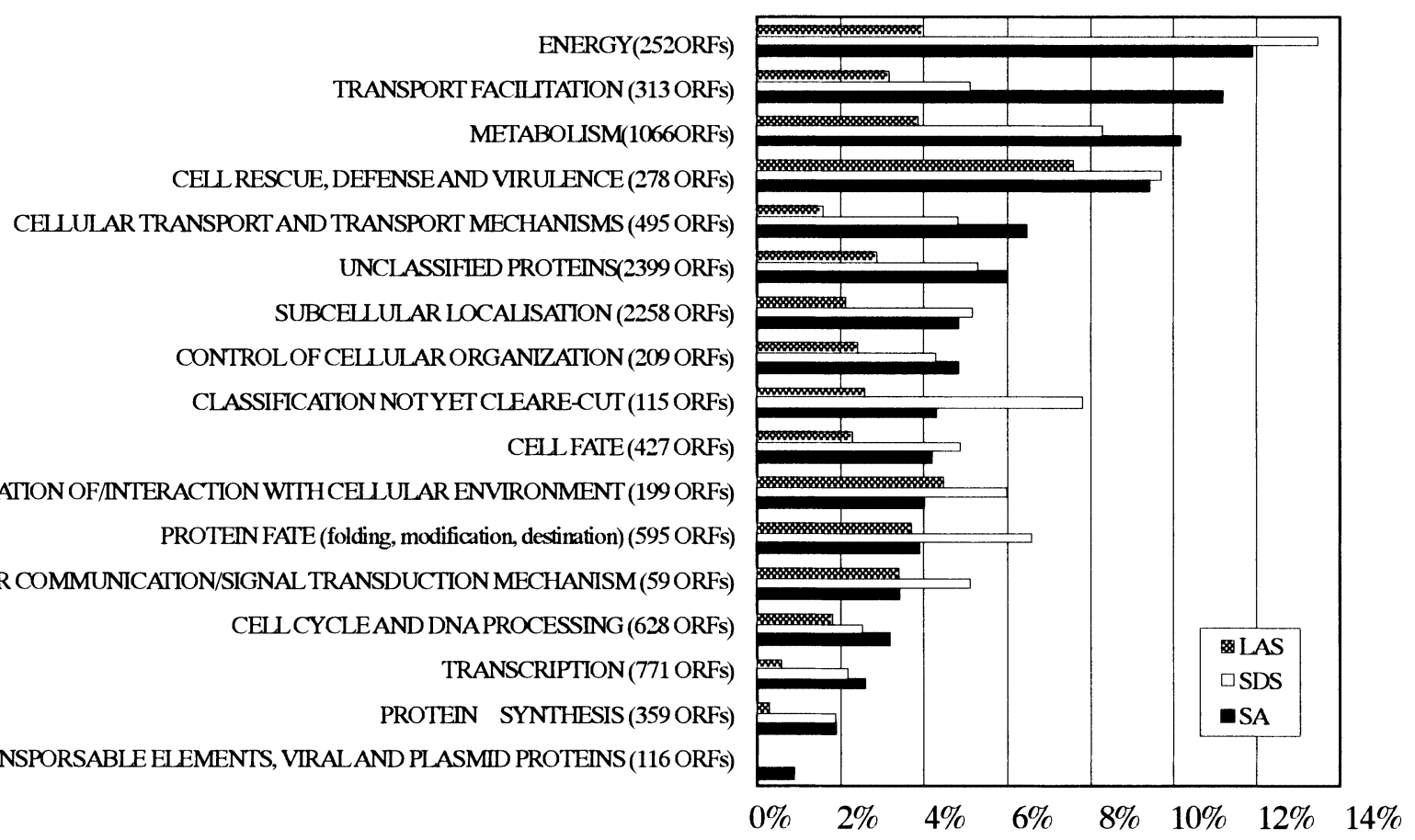

Fig. 4 Characterization of Induced Genes by the Functional Categories. X-axis indicate percent of induced genes (number of induced genes / number of genes in each subcategory $\times 100$ ). 


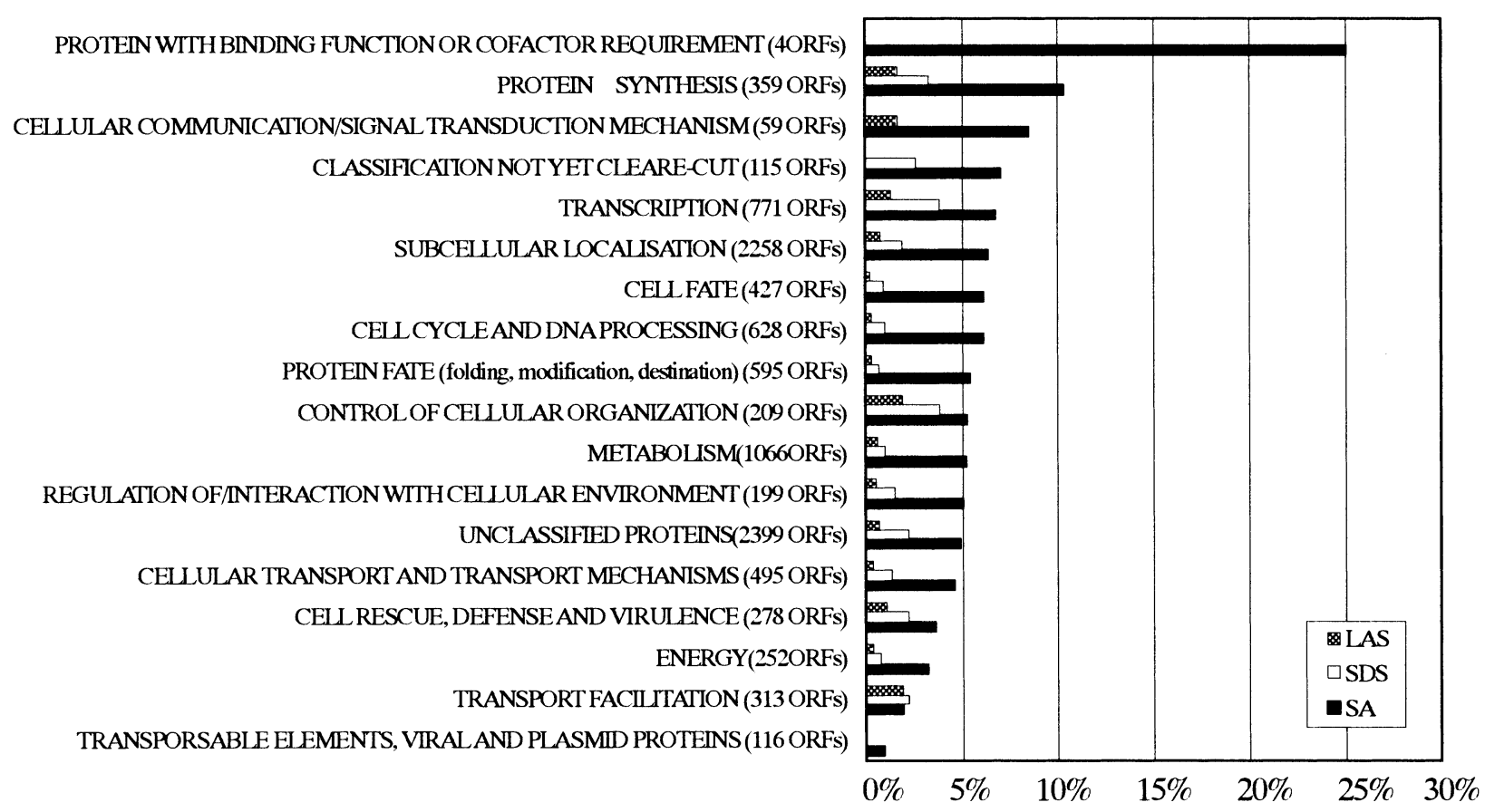

Fig. 5 Characterization of Repressed Genes by the Functional Categories. X-axis indicate percent of induced genes (number of induced genes / number of genes in each subcategory $\times 100$ ).

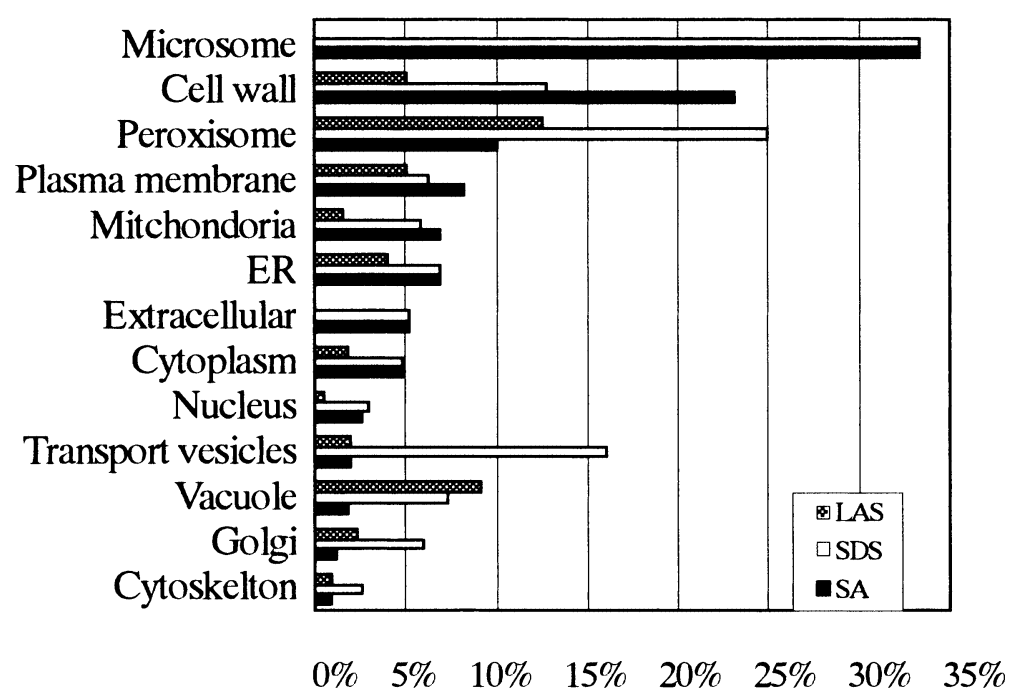

Fig. 6 Characterization of Induced Genes by the Functional Categories of "Localization". X-axis indicate percent of induced genes (number of induced genes / number of genes in each subcategory $\times 100)$. 
Table 3 The List of Induced Genes that Products are Localized in Plasma Membrane.

\begin{tabular}{|c|c|c|c|c|}
\hline Gene Name & SA & SDS & LAS & Description \\
\hline AGP1 & $\underline{4.7}$ & 0.6 & 0.6 & Amino acid permease \\
\hline HNM1 & $\underline{3.3}$ & 0.7 & 0.6 & Transporter for choline and nitrogen mustard \\
\hline HXT4 & $\underline{3.2}$ & 1.3 & 1.0 & High-affinity glucose transporter \\
\hline GAL2 & $\underline{3.0}$ & 0.8 & 0.7 & Galactose permease \\
\hline HSP30 & $\underline{2.9}$ & 0.7 & 0.7 & Protein induced by heat shock \\
\hline ITR1 & $\underline{2.9}$ & 1.6 & - & Myo-inositol transporter \\
\hline HXT6 & $\underline{2.6}$ & $\underline{2.3}$ & 1.0 & Hexose transporter \\
\hline YOR1 & $\underline{2.5}$ & $\underline{2.9}$ & $\underline{3.9}$ & $\mathrm{ABC}$ transporter \\
\hline HXT2 & $\underline{2.4}$ & 1.6 & 1.2 & High affinity hexose transporter- 2 \\
\hline MAL31 & $\underline{2.4}$ & 0.8 & 0.8 & Maltose permease \\
\hline HXT12 & $\underline{2.1}$ & 1.5 & 1.3 & Hexose permease \\
\hline HXT9 & $\underline{2.1}$ & 1.1 & 1.6 & Hexose permease \\
\hline MEP2 & $\underline{2.1}$ & 0.9 & 1.0 & Ammonia transport protein \\
\hline PLB1 & 1.9 & 1.9 & $\underline{3.7}$ & Phospholipase B (lypophospholipase) \\
\hline YPS1 & 1.9 & $\underline{2.9}$ & $\underline{3.2}$ & GPI-anchored aspartic protease \\
\hline YPS3 & 1.8 & 1.5 & $\underline{2.4}$ & GPI-anchored aspartic protease \\
\hline GSC2 & 1.8 & $\underline{2.5}$ & $\underline{3.5}$ & Catalytic component of 1,3-beta-D-glucan synthase subunit \\
\hline HXT3 & 1.6 & $\underline{2.1}$ & 1.3 & Low-affinity glucose transporter \\
\hline PMP3 & 1.6 & $\underline{2.3}$ & 1.2 & Hypothetical transmembrane protein \\
\hline PDR5 & 1.3 & $\underline{3.2}$ & $\underline{3.2}$ & Multidrug resistance transporter \\
\hline HXT7 & 1.2 & $\underline{2.3}$ & 1.1 & Hexose transporter \\
\hline PST1 & 1.0 & $\underline{2.1}$ & $\underline{2.6}$ & The gene product has been detected among the proteins secreted by regenerating protoplasts \\
\hline CHS1 & 0.9 & $\underline{2.8}$ & $\underline{3.1}$ & Chitin synthase 1 \\
\hline
\end{tabular}

The number with line shows genes induced by the detergent treatment

た遺伝子が分類されていた，「エネルギー系」のカテゴ リーの遺伝子をさらに細かく見るために，「エネルギー 系」に属するサブカテゴリーで分類した結果を Fig. 8 に示す。スピクリスポール酸では「発酵」に関わる遺 伝子が最も多く誘導されていたが，SDSとLASでは 「脂肪酸の酸化」に関わる遺伝子が多く誘導されてい た。エネルギー生成の最終段階である, 酸化的リン酸 化反応の代謝経路に注目すると, SDS で酸化的リン酸 化に関わる遺伝子である $\operatorname{COX} 4, \operatorname{COX} 5 B, \operatorname{COX} 8$, COX12，QCR8，QCR7が誘導されていた（10）。これら COX 系の遺伝子は, ミトコンドリアにおける電子伝達 系で $\mathrm{O}_{2}$ による還元型シトクロム $\mathrm{c}$ の酸化を触媒する, 複合体 IVのマトリックス側で機能している $(10)$ 。同様 に $Q C R$ 系の遺伝子は, シトクロム $\mathrm{c}$ にる還元型 $\mathrm{CoQ}$ の触媒をする，複合体 III で機能していることが示され ている（10）。一方，スピクリスポール酸ではSDHI が 顕著に誘導されていた。SDHI は, $\mathrm{CoQ} に よ る ~ \mathrm{FADH}_{2}$ の酸化を触媒する複合体 II で機能する遺伝子である (10)。SDS では, NADH の酸化を触媒する, 酸化的リ ン酸化反応に関わる遺伝子が誘導されるのに対して,
スピクリスポール酸では, FADH2 の酸化を触媒する, 酸化的リン酸化反応に関わる遺伝子が誘導されていた (Fig. 9)。

\section{6 代謝系に関する遺伝子}

3 種類の界面活性剤で共通して強く誘導していた遺伝 子が属する，「代謝系」のカテゴリーを細かく見ること にした（Fig. 10）。スピクリスポール酸では，「リン酸 代謝系」の遺伝子が最も高い割合で誘導されていた。 既報のようにSDS, LAS では「脂質, 脂肪酸とイソプ レン系の代謝」に関わる遺伝子が最も高い割合で誘導 されていた。各界面活性剂で誘導された遺伝子が属す るサブカテゴリーが異なることから，それ古れの界面 活性剤により誘導された遺伝子で「代謝系」に分類さ れた遺伝子を Table 4, Table 5 に示した。「代謝系」 に分類される，スピクリスポール酸による誘導遺伝子 を基準に 3 種類の界面活性剤の発現レベルを比較する と, SDS, LAS で処理した遺伝子はほとんど誘導され ていなかった（Table 4）。さらに, SDSによる誘導遺 伝子を基準に 3 種類の界面活性剂の発現レベルを比較 


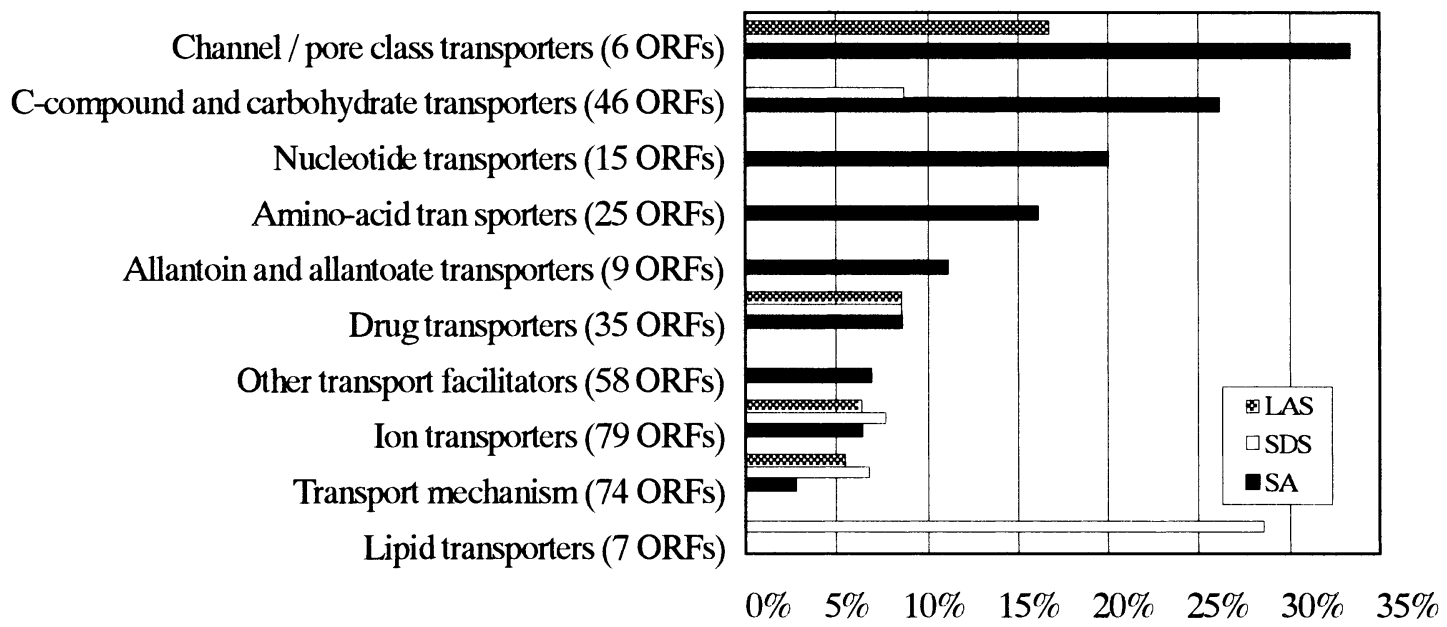

Fig. 7 Characterization of Induced Genes by the Functional Categories of "Transport facilitation". X-axis indicate percent of induced genes (number of induced genes / number of genes in each subcategory $\times 100$ ).

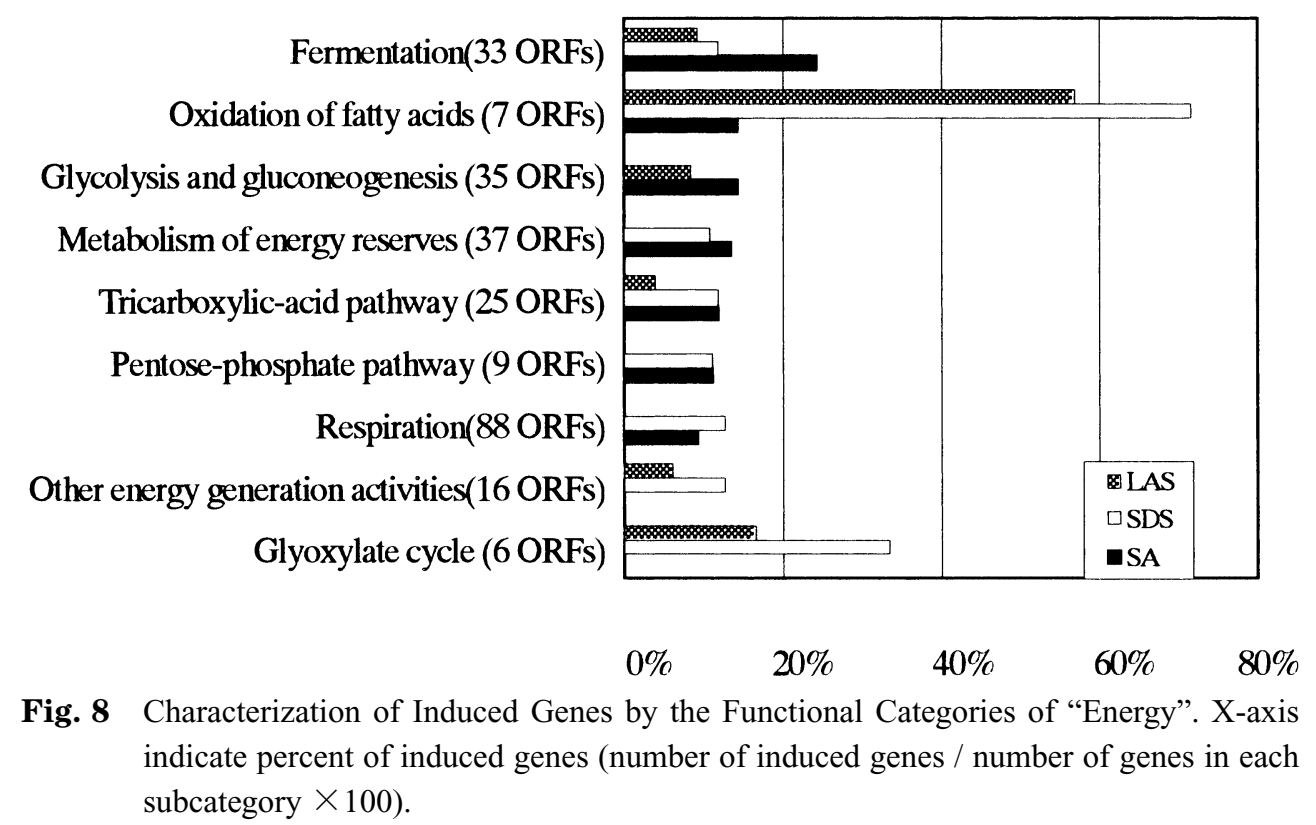

すると（Table 5), SDS と LAS では同じ遺伝子が誘導 されていたが，スピクリスポール酸では共通して誘導 されている遺伝子がほとんどなかった。Table 4 扎よび Table 5 から，同じカテゴリーの遺伝子が共通して高い 割合で誘導されていても, 誘導されている遺伝子は異 なることが分かり，代謝に対する影響という点におい ても，スピクリスポール酸とSDS, LAS では相違があ ることが推察された。

\section{$3 \cdot 7$ 脂肪酸代謝}

Fig. 10 に扔いて，SDS，LASでは，「脂肪酸代謝」 に関わる遺伝子が高い割合で誘導されていることを確 認したことから, KEGG (http://www.genome.ad.jp/ $\mathrm{kegg} / \mathrm{kegg} 2 . \mathrm{html})$ のデータベースを元に脂肪酸代謝の 経路について解析した。脂肪酸代謝に関わる遺伝子で SDS 処理により誘導された遺伝子はPOX1, POT1, FAA2, FOX2, ALD4, ADH5であった (10)。これらの 遺伝子は全てペルオキシソームに局在しており, SDS により引き起こされる脂肪酸代謝はペルオキシソーム 


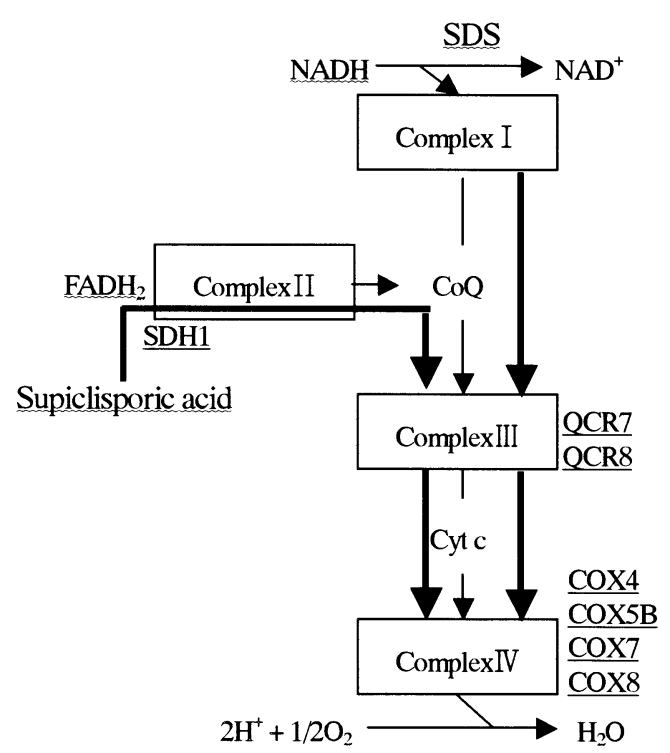

Fig. 9 Oxidative Phosphorylation Pathway. Induced genes by SDS treatment suggests the oxidation through NADH of complex I, complex III, complex IV . Induced genes by supiculisporic acid treatment suggests the oxidation through $\mathrm{FADH}_{2}$ of complex II, complex III and complex IV. The induced genes by SDS and supiculisporic acid was show by common name with bold type.
内での $\beta$ 酸化であることが推察される。ペルオキシ ソームに打ける $\beta$ 酸化は, $\mathrm{C}_{8}$ 以上の長鎖脂肪酸を短く して，ミトコンドリアでの $\beta$ 酸化で分解しやすくする ために起こる (10)。LAS ではPOX1 とPOT1 が誘導さ れており, SDSほどではないがペルオキシソームによ る $\beta$ 酸化が行われていると考えることができる。一方, スピクリスポール酸では，ペルオキシソームに局在す る遺伝子はPOX1のみであった。しかし, SDS と共に， 他の脂肪酸代謝に関わり，ミトコンドリアに局在する $A L D 4$ と $A D H 5$ は強く誘導されていた。このことから, SDS と LAS ではペルオキシソームで $\beta$ 酸化を受けてい ることが推察されたが, スピクリスポール酸では主と して，ミトコンドリアで $\beta$ 酸化を受けていると考える ことができる。

\section{$3 \cdot 8$ 細胞の救出・防御・毒性に関する遺伝子}

「細胞の救出・防御・毒性」のカテゴリーに含まれる 遺伝子はSDS, LAS で最も高い割合で誘導されており, スピクリスポール酸でも比較的高い割合で誘導されて いた。そこで,「細胞の救出・防御・毒性」のカテゴ リーに分類される遺伝子のうち，それぞれの界面活性 剂で強く誘導された遺伝子から 10 種ずつを併せて Table 6 に示した。SA では低温ショック系の遺伝子で あるTIR1, TIR2 が強く誘導されているのに対して, 既 報のように SDS では酸化ストレス系の遺伝子である GRX1，GPX1，TTR1，HYR1，CTT1，GTT2 が誘導され ていた（10）。また，LASに扎ても，酸化ストレス系 の遺伝子である $G R X 1, G T T 1$ が誘導されていた。 $\mathbf{3} \cdot \mathbf{7}$ で述べたように, SDS と LAS ではペルオキシソームで 脂肪酸の酸化を受けていると考えることができる。こ の $\beta$ 酸化に関与する $P O X 1$ 産物によって起こる反応生

\section{Phosphate metabolism (33 ORFs)}

C-compound and carbohydrate metabolism(415 ORFs)

Nitrogen and sulfur metabolism (67 ORFs)

Lipid, fatty-acid and isoprenoid metabolism(213 ORFs)

$$
\text { Amino acid metabolism(204 ORFs) }
$$

Metabolism of vitamins, cofactors, and prosthetic groups (86ORFs)

Nucleotide metabolism(148 ORFs)

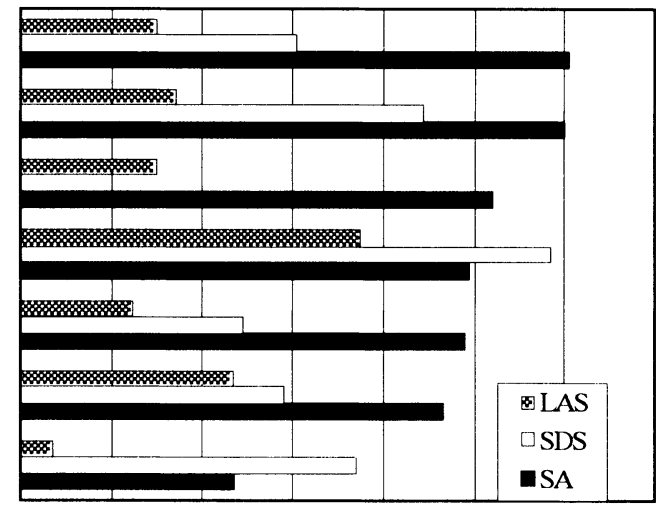

$\begin{array}{llllllll}0 \% & 2 \% & 4 \% & 6 \% & 8 \% & 10 \% & 12 \% & 14 \%\end{array}$

Fig. 10 Characterization of Induced Genes by the Functional Categories of "Metabolism". X-axis indicate percent of induced genes (number of induced genes / number of genes in each subcategory $\times 100$ ). 
Table 4 The List of Genes in the Category of "Metabolism" Induced by Supiculisporic Acid Treatment.

\begin{tabular}{lccrl}
\hline Gene Name & SA & SDS & LAS & Description \\
\hline HEM13 & $\underline{\mathbf{5 . 7}}$ & 0.7 & 0.7 & Coproporphyrinogen III oxidase \\
YDL037C & $\underline{\mathbf{5 . 5}}$ & 0.4 & 0.9 & Strong similarity to glucan 1,4-alpha-glucosidase \\
OPI3 & $\underline{\mathbf{5 . 0}}$ & $\underline{\mathbf{2 . 5}}$ & $\underline{\mathbf{3 . 1}}$ & Methylene-fatty-acyl-phospholipid synthase \\
AGP1 & $\underline{\mathbf{4 . 7}}$ & 0.6 & 0.6 & Amino acid permease \\
BIO2 & $\underline{\mathbf{4 . 4}}$ & 0.7 & 0.8 & Biotin synthase \\
INO1 & $\underline{\mathbf{4 . 3}}$ & 1.7 & $\underline{\mathbf{1 0 . 4}}$ & L-myo-inositol-1-phosphate synthase \\
YIR035C & $\underline{\mathbf{4 . 3}}$ & 0.9 & 1.2 & Similarity to human corticosteroid 11-beta-dehydrogenase \\
CHO1 & $\underline{\mathbf{4 . 1}}$ & $\underline{\mathbf{3 . 2}}$ & 1.7 & Phosphatidylserine synthase \\
OLE1 & $\underline{\mathbf{4 . 0}}$ & 1.7 & 1.1 & Delta-9-fatty acid desaturase \\
ELO1 & $\underline{\mathbf{3 . 9}}$ & 1.9 & 0.9 & Elongation enzyme 1 \\
POX1 & $\underline{\mathbf{3 . 9}}$ & $\mathbf{9 . 2}$ & $\underline{\mathbf{3 . 0}}$ & Fatty-acyl coenzyme A oxidase \\
SUC2 & $\underline{\mathbf{3 . 9}}$ & 1.4 & 1.2 & Invertase (sucrose hydrolyzing enzyme) \\
ADH5 & $\underline{\mathbf{3 . 9}}$ & $\underline{\mathbf{2 . 0}}$ & 1.4 & Alcohol dehydrogenase isoenzyme V \\
MIR1 & $\underline{\mathbf{3 . 8}}$ & 0.7 & 1.0 & Mitochondrial phosphate transport protein. (MCF) \\
MAL33 & $\underline{\mathbf{3 . 7}}$ & 1.0 & 0.8 & MAL-activator protein \\
APT2 & $\underline{\mathbf{3 . 7}}$ & 0.7 & 1.1 & Adenine Phosphoribosyltransferase \\
HXK1 & $\underline{\mathbf{3 . 6}}$ & $\mathbf{2 . 2}$ & 1.4 & Hexokinase I (PI) (also called Hexokinase A) \\
YFL057C & $\underline{\mathbf{3 . 6}}$ & 1.3 & 1.6 & Strong similarity to aryl-alcohol dehydrogenases \\
TIP1 & $\underline{\mathbf{3 . 6}}$ & 0.4 & 0.5 & Cell wall mannoprotein \\
TES1 & $\underline{\mathbf{3 . 5}}$ & 1.5 & 1.5 & Peroxisomal acyl-CoA thioesterase \\
\hline
\end{tabular}

The number with line is induced genes treated with detergents.

Table 5 The List of Genes in the Category of "Metabolism" Induced by SDS Treatment.

\begin{tabular}{lcccl}
\hline Gene Name & SA & SDS & LAS & Description \\
\hline HSP12 & 0.8 & $\underline{\mathbf{9 . 3}}$ & 1.6 & 12 kDa heat shock protein \\
POX1 & $\underline{\mathbf{3 . 9}}$ & $\underline{\mathbf{9 . 2}}$ & $\underline{\mathbf{3 . 0}}$ & Fatty-acyl coenzyme A oxidase \\
YPL088W & 1.7 & $\underline{\mathbf{8 . 2}}$ & $\underline{\mathbf{9 . 7}}$ & Strong similarity to aryl-alcohol dehydrogenase \\
ECI1 & 1.6 & $\underline{\mathbf{8 . 1}}$ & $\underline{\mathbf{4 . 0}}$ & Peroxisomal d3,d2-enoyl-CoA isomerase \\
MET30 & 1.6 & $\underline{\mathbf{5 . 7}}$ & $\underline{\mathbf{7 . 5}}$ & Met30p contains five copies of WD40 motif \\
GRE2 & 1.4 & $\underline{\mathbf{5 . 4}}$ & $\underline{\mathbf{4 . 6}}$ & Putative reductase \\
YGR043C & 1.8 & $\underline{\mathbf{4 . 8}}$ & 1.5 & Strong similarity to transaldolase \\
PHO89 & 0.9 & $\underline{\mathbf{4 . 3}}$ & $\underline{\mathbf{4 . 9}}$ & Nat-coupled phosphate transport protein \\
DLD1 & 1.2 & $\underline{\mathbf{4 . 0}}$ & $\underline{\mathbf{2 . 5}}$ & D-lactate ferricytochrome c oxidoreductase \\
PDR16 & 1.1 & $\underline{\mathbf{3 . 9}}$ & $\underline{\mathbf{4 . 0}}$ & Homologous to Pdr17p and Sec14p \\
RIB5 & 0.9 & $\underline{\mathbf{3 . 8}}$ & $\underline{\mathbf{3 . 2}}$ & Riboflavin synthase alpha-chain \\
GPM2 & 0.7 & $\underline{\mathbf{3 . 7}}$ & 1.9 & Phosphoglycerate mutase, involved in glycolysis \\
PXA1 & 1.8 & $\underline{\mathbf{3 . 5}}$ & 1.5 & ABC family long-chain fatty acid transporter \\
YBR056W & 0.6 & $\underline{\mathbf{3 . 4}}$ & $\underline{\mathbf{2 . 5}}$ & Homolog to glucan-1,3-glucosidase 2 \\
ARA1 & 0.5 & $\underline{\mathbf{3 . 4}}$ & $\underline{\mathbf{2 . 1}}$ & D-arabinose dehydrogenase \\
PUT1 & 1.2 & $\underline{\mathbf{3 . 4}}$ & $\underline{\mathbf{2 . 0}}$ & Proline oxidase \\
JEN1 & $\underline{\mathbf{2 . 7}}$ & $\underline{\mathbf{3 . 3}}$ & 1.6 & Carboxylic acid transporter protein homolog \\
CHO1 & $\underline{\mathbf{4 . 1}}$ & $\underline{\mathbf{3 . 2}}$ & 1.7 & Phosphatidylserine synthase \\
PDR5 & 1.3 & $\underline{\mathbf{3 . 2}}$ & $\underline{\mathbf{3 . 2}}$ & Multidrug resistance transporter \\
LSC2 & 0.9 & $\underline{\mathbf{3 . 1}}$ & 1.9 & Succinate-CoA ligase (ADP-forming) \\
\hline
\end{tabular}

The number with line is induced genes treated with detergents. 
Table 6 The List of Genes in the Category of "Cell Rescue, Defense and virulence" Induced by Each Detergents Treatment.

\begin{tabular}{lrrrl}
\hline Gene Name & SA & SDS & LAS & Description \\
\hline TIR1 & $\underline{\mathbf{8 . 6}}$ & 0.7 & 1.0 & Cold-shock induced protein of the Srp1p \\
TIR2 & $\underline{\mathbf{4 . 2}}$ & 0.7 & 1.3 & Induced by cold shock \\
YBR293W & $\underline{\mathbf{4 . 0}}$ & 1.4 & 1.0 & Probable multidrug resistance protein \\
ADH5 & $\underline{\mathbf{3 . 9}}$ & $\underline{\mathbf{2 . 0}}$ & 1.4 & Alcohol dehydrogenase isoenzyme V \\
YER187W & $\underline{\mathbf{3 . 8}}$ & 0.8 & 1.0 & Similar to killer toxin \\
TIP1 & $\underline{\mathbf{3 . 6}}$ & 0.4 & 0.5 & Cell wall mannoprotein \\
SRL1 & $\underline{\mathbf{3 . 3}}$ & 0.8 & 1.1 & Suppressor of rad53 lethality \\
AZR1 & $\underline{\mathbf{3 . 2}}$ & 1.2 & $\underline{\mathbf{3 . 8}}$ & Small molecule transport/MFS-MDR \\
GTT2 & $\underline{\mathbf{3 . 0}}$ & $\underline{\mathbf{2 . 1}}$ & 1.9 & Glutathione transferase \\
CTT1 & $\underline{\mathbf{3 . 0}}$ & $\underline{\mathbf{2 . 0}}$ & 0.9 & Cytoplasmic catalase T \\
GTT1 & 1.8 & 1.9 & $\underline{\mathbf{2 . 7}}$ & Glutathione transferase \\
HYR1 & 1.8 & $\underline{\mathbf{2 . 7}}$ & 1.7 & Putative glutathione-peroxidase \\
TTR1 & 1.8 & $\underline{\mathbf{2 . 9}}$ & 1.4 & Glutaredoxin \\
YOR273C & 1.5 & $\underline{\mathbf{2 . 9}}$ & $\underline{\mathbf{3 . 4}}$ & Similarity to resistance proteins \\
RTA1 & 1.4 & $\underline{\mathbf{8 . 8}}$ & $\underline{\mathbf{1 3 . 6}}$ & Involved in 7-aminocholesterol resistance \\
PDR5 & 1.3 & $\underline{\mathbf{3 . 2}}$ & $\underline{\mathbf{3 . 2}}$ & Multidrug resistance transporter \\
MAC1 & 1.2 & $\underline{\mathbf{3 . 3}}$ & $\underline{\mathbf{2 . 7}}$ & Metal-binding transcriptional activator \\
GPX1 & 1.2 & $\underline{\mathbf{3 . 1}}$ & 1.8 & Glutathione peroxidase paralogue \\
YLL057C & 1.1 & 1.3 & $\underline{\mathbf{3 . 0}}$ & Similarity to E.coli dioxygenase \\
YLR046C & 1.1 & $\underline{\mathbf{5 . 2}}$ & $\underline{\mathbf{5 . 0}}$ & Strong similarity to Rta1p and Rtm1p protein \\
ATX1 & 0.9 & $\underline{\mathbf{2 . 4}}$ & $\underline{\mathbf{2 . 9}}$ & Putative copper binding/homeostasis protein \\
YSR3 & 0.8 & $\underline{\mathbf{2 . 4}}$ & $\underline{\mathbf{3 . 5}}$ & DHS-1-P phosphatase \\
HSP12 & 0.8 & $\underline{\mathbf{9 . 3}}$ & 1.6 & 12 kDa heat shock protein \\
GRX1 & 0.7 & $\underline{\mathbf{4 . 5}}$ & $\underline{\mathbf{2 . 6}}$ & Glutaredoxin \\
\hline & & & & \\
PAn & & &
\end{tabular}

The number with line isinduced genes treated with detergents.

成物は， $\mathrm{H}_{2} \mathrm{O}_{2}$ であることが知られており，SDS と LAS において酸化ストレス系の遺伝子が誘導されたことと 一致する。

$$
4 \text { まとめ }
$$

スピクリスポール酸と SDS 打よびLAS による, 酵母 DNA マイクロアレイのデータ解析を比較した結果, 以 下のことが明らかになった。

1）階層的クラスター解析により, 他の化学物質の遺 伝子発現プロファイルと比較したところ，スピクリス ポール酸とSDS, LAS の遺伝子発現プロファイルは類 似していた。しかし，強く誘導された遺伝子を比較す ると，既報のようにSDS と LAS では類似していたが， スピクリスポール酸では異なる結果を示していた。さ らに，誘導遺伝子を MIPSのカテゴリーで機能別に分 類した結果, 高い割合で誘導されたカテゴリーは類似 していたが，カテゴリーに分類された誘導遺伝子を解 析したところ, SDS と LASでは類似しており, スピク
リスポール酸では異なることが推察された。以上のこ とより，スピクリスポール酸はSDS と LAS とは生体に 対する影響が異なることが示唆された。また, DNA マ イクロアレイを用いた解析では, 少なくともスピクリ スポール酸とSDS, LAS を生体影響という観点で区別 できることが示された。

2）スピクリスポール酸と SDSの代謝という点に着目 して解析した結果, (1)脂肪酸代謝に関与する遺伝子の 局在性に打いて, SDSではペルオキシソームに局在す る遺伝子が多く誘導されていたが，スピクリスポール 酸ではミトコンドリアに局在する遺伝子が多かった。 (2)酸化的リン酸化では，SDSで，NADHの酸化を触媒 する反応系に関わる遺伝子が誘導されるのに対して, スピクリスポール酸では, $\mathrm{FADH}_{2}$ の酸化を触媒する反 応系に関わる遺伝子が誘導されていた。(3) SDSではミ トコンドリアの $\beta$ 酸化系の遺伝子も誘導されていたが, 主としてペルオキシソームの $\beta$ 酸化系が強く誘導され ていた。スピクリスポール酸では, 主としてミトコン 
ドリアの $\beta$ 酸化系が誘導されていた。(4) SDSでは酸化 ストレスが顕著に発生していた。これらのことから， SDSではペルオキシソームを中心として代謝され， $\mathrm{H}_{2} \mathrm{O}_{2}$ を介した酸化ストレスを強く誘導するが，スピク リスポール酸では，ミトコンドリアを中心として代謝 され，酸化ストレスはほとんど発生していないと考え られる。これは, SDSのアルキル鎖の長さがスピクリ スポール酸のアルキル鎖の長さよりも長いことと関係 して打り, 界面活性剤による酸化ストレスの誘導は, アルキル鎖の長さが影響していることが示唆された。 しかしながら, 親水基の影響について, 今回は検討し ていないため, 今後の検討課題である。

以上の結果は, DNA マイクロアレイ技術が, 各種化 学物質の生体影響を評価する上で, 有効である可能性 を示しており，本法が界面活性剤の安全性および毒性 の新しい評価・解析手法として普及することを期待し たい。

\section{謝 辞}

本研究の一部は, NEDO 民間基盤技術研究試験研究 “環境化学物質の簡易型化学物質推定・毒性評価システ ムの開発”の委託先であるダイキン環境研究所からの 再委託により実施している。

\section{Reference}

1. Y. ISHIGAMI, Properties and Special functions of Biosurfactants, Hyomen, Vol. 27, 457-472 (1989).

2. Y. ISHIGAMI, Recent Advance of R\&D of Biosurfactants, Hyomen, Vol. 35, 515-523 (1997).

3. M. OSMAN, Y. ISHIGAMI, K. FURUSAWA and H, HOLMSEN, Multicarboxylic Biosurfactants as a Model for Designing Hard Water and High Salt Tolerance, J. Jpn Oil Chem. Soc., Vol. 46, 741-746 (1997).

4. Suidousui suishitsu kijyun ichiran (Kijyun46koumoku).

5. S. SIRISATTHA, Y. MOMOSE, E. KITAGAWA and H. IWAHASHI, Toxicity of Anionic Detergents by Saccharomyces cerevisiae Microarray Analysis, Water Res.,Vol. 38, 61-70 (2004).

6. Y. ISHIGAMI, S.YAMAZAKI and Y. GAMA, Surface Active Properties of Polycarboxylic Biosurfactant from Spiculisporic acid, Kankyou gijyutsu kenkyujyo houkoku, Vol. 80, No.6, pp. 223-230 (1985).

7. H. IWAHASHI, Maicroarray, DNAchip-KOREKARA NO GIJYUTU-, KANKYOU GIJYUTSU, Vol. 31, No. 9, 679-685 (2002).

8. Y. MOMOSE and H. IWAHASHI, Bioassay of Cadmium Using a DNA Microarry: Genome-Wide Expression Patterns of Saccharomyces Cerevisiae, Environ. Toxcol. Chem., Vol. 20, 23532360 (2001).

9. S. KURITA, E. KITAGAWA, C. KIM, Y. MOMOSE and H. IWAHASHI, Studies on the Antimicrobial Mechanisms of Capsaicin Using Yeast DNA Microarray, Biosci. Biotechnol. Biochem., Vol. 66(3), 532-536 (2002).

10. D. VOET and J. VOET, Voet Biochemistry (JYOU) (GE), Vol. 1, 1 (1992). 